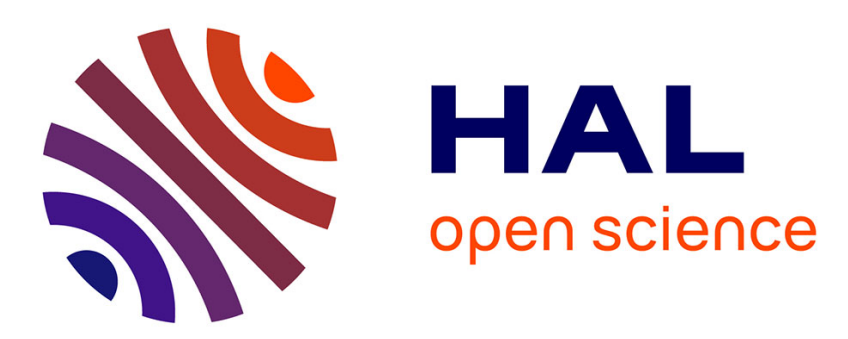

\title{
Coming out and coming back: Rural gay migration and the city
}

Alexis Annes, Meredith Redlin

\section{To cite this version:}

Alexis Annes, Meredith Redlin. Coming out and coming back: Rural gay migration and the city. Journal of Rural Studies, 2012, 28, pp.56 - 68. 10.1016/j.jrurstud.2011.08.005 . hal-01564756

\section{HAL Id: hal-01564756 \\ https://hal.science/hal-01564756}

Submitted on 20 Sep 2017

HAL is a multi-disciplinary open access archive for the deposit and dissemination of scientific research documents, whether they are published or not. The documents may come from teaching and research institutions in France or abroad, or from public or private research centers.
L'archive ouverte pluridisciplinaire HAL, est destinée au dépôt et à la diffusion de documents scientifiques de niveau recherche, publiés ou non, émanant des établissements d'enseignement et de recherche français ou étrangers, des laboratoires publics ou privés. 


\title{
Coming Out and Coming Back: Rural Gay Migration and the City
}

\author{
Dr. Alexis ANNES ${ }^{1}$ (corresponding author) \\ South Dakota State University \\ Department of Sociology and Rural Studies \\ SSB 203, Box 504 \\ Brookings, SD 57007 \\ United-States of America \\ Phone: (605)688 4084 \\ Fax : (605)688 6354: \\ alexis.annes@gmail.com \\ Dr. Meredith REDLIN \\ South Dakota State University \\ Department of Sociology and Rural Studies \\ SSB 203, Box 504 \\ Brookings, SD 57007 \\ United-States of America \\ Phone: (605)688 4084 \\ Fax : (605)688 6354: \\ meredith.redlin@sdstate.edu
}

\begin{abstract}
This research focuses on the complex meaning and role of the city in American and French rural gay men's imaginary and life experience. It explores how gay men who grew up in the country build their sense of self through back-and-forth movement from rural to urban spaces. Therefore, it questions traditional gay migration studies, which have often equated gay migration and rural urban migration, positing a uni-directional pattern. After contextualizing rural male homosexuality, this paper presents four life itineraries which highlight the central role the city has for rural gay men when exploring their same-sex desires and attractions. Based on the analysis of their life narratives, we show that for most of them, their coming out, their first same-sex experience, and coming to terms with their sexuality happens "far from home" in a city or a college town. However, this research suggests that the city has a more ambivalent role for rural gay men. While the city exists as a space of social practices where alternative sexualities can be experienced and explored, at the same time for many rural gay men the city remains substantially unattractive. In their view, the perceived "effeminizing power" of the city questions and challenges their attraction for this space. Therefore, the experience of the city becomes both liberating and disciplinary--liberating because it allows the exploration of their same sex desires and attractions, disciplinary because it (re)presents a gay identity in which they find no resonance. Thus this research indicates that rural gay migration to the urban spaces, which is key to identity formation,
\end{abstract}

\footnotetext{
${ }^{1}$ Present/Permanent Address: Ecole d'Ingénieurs de PURPAN ; 75, voie du TOEC ; BP 57611 ; 31076 TOULOUSE Cedex 3 ; Tél : (33) 561153086 ;Fax : (33) 561153060 ; e-mail: alexis.annes@purpan.fr
} 
includes not only departure to the city but also a necessary return to the country to maintain rural gay men's understanding of themselves.

\section{Introduction}

This article explores the link between migration patterns of gay men who grew up in French and North American rural places and their process of identity construction. Particularly, it focuses on how these men build their sense of self and their subjectivities through back-and-forth movements from the country to the city. Since the 1990s, rural scholars have given more attention to diversity existing in rural studies (Cloke and Little, 1997). Based on the acknowledgement that rurality has been portrayed from a White Anglo perspective, Panelli, Hubbard, Coombes and Suchet-Pearson (2009) began the project of de-centering White rurality by exploring the role of ethnicity and indigeneity in the construction of this diverse space. We further this work, asserting that the perspective used to understand rurality was not only White and Anglo, but also heterosexual. We expand the existing body of work about sexuality and rurality (Bell, 2000, 2006; Gorman-Murray, Waitt and Gibson, 2008; Kirkey and Forsyth, 2001; Smith and Holt, 2005; Valentine, 1997) by focusing on the experience of self-identified gay men who grew up in French and US rural spaces ${ }^{2}$. Accepting that identify formation is a complex process shaped by individuals' movements from one space to another (Andrews, 2009), this article characterizes how this process emerges for a select group of rural gay men. Identity, states Woodward (2002), is a lifelong and dynamic process with possibilities of shifts and contradictions occurring in the mundane context of everyday life (Robinson, 2008). Therefore,

\footnotetext{
${ }^{2}$ Our goal is to understand the interconnectedness between rurality and sexuality from the perspective of non-heterosexual and/or LGBTQ individuals. However, we are not trying to create a universal and uniform experience of the rural. We recognize that non-heterosexual and/or LGBTQ experiences are plural and sometimes contradictory. Therefore, this study emphasizes the situated knowledge (Haraway, 1988) of self-identified gay men and, consequently, only reports on their own perspectives and representations.
} 
our research questions how the process of forming sexual (and gendered) identities for these rural gay men works through an attraction and, concurrently, a repulsion of the "city." In their life narrative, the "city" is viewed as both a fantasized place and an experienced space of representations as well as practices. As noted by Andrews (2009:168), "gendered identities are not given but emerge in practice and as active processes through, in part, the use of space." Following this argument, we explore how both the country and city (and their situated impressions of them) affect rural gay men's identification processes. Other theorists have pointed out the need to not only focus on factors such as race, ethnicity, age, gender, and class when trying to understand subjectivities that constitute gayness, but also the need to incorporate geographic location as a decisive factor (Inness, 2004; Knopp, 2006; Knopp and Brown, 2003). For instance, Knopp argues that "the idea of movement, flux, and flow as important ontological sites in and of themselves, for both gay men and geographical thought, has been underappreciated and underdeveloped in the literature of both" (2006:219). This article explores more deeply the relationship between spatial movements and the building of rural gay men's sense of self.

Cities have been portrayed as "homosexual paradises" whose tolerance of nonheterosexual identities and sexual practices attracted numerous rural individuals trying to escape the conservative culture of their place of birth (Blidon, 2008; Rubin, 1993; Valentine and Skelton, 2003; Weston, 1995). Cities have also become catalysts in the construction of contemporary gay cultures ${ }^{3}$ whereas rural places have commonly been contrasted as cultural vacuums (Aldrich, 2004; Knopp, 1998; Mort, 1995). This rural/urban distinction appears so embedded in consciousness (and in research) that it has become a source of understanding of gay

\footnotetext{
${ }^{3}$ Our use of the term gay reflects the terminology presents in the review of literature and encompasses both gay men and lesbians.
} 
individuals' relocation and migration, broadly, and in this research, of rural gay men's relocation and migration, specifically (Gorman-Murray, 2007; Knopp and Brown, 2003). Past gay migration studies suggest that due to feeling out of place in the rural communities where they grew up, gay individuals needed spatial displacement and relocation to urban spaces in order to be able to express freely their alternative sexual desires and to develop their non-heterosexual identity (Binnie, 2004; Brown, 2000, Cant, 1997; Chauncey, 1994). In fact, these studies conflate gay migration with rural-urban displacement where rural areas are portrayed as "constraining places" for homosexual sexuality in contrast to urban areas which are portrayed as "liberating places." Recently, this unidirectional approach to gay migration research has been challenged for: (1) giving a simplistic and partial view and understanding of gay individuals' movements, (2) assuming the impossibility of developing gay identity in rural areas and the necessity of going to urban centers to develop one, and (3) suggesting the existence of a unique, "fully-formed and fixed" identity in urban centers (Gorman-Murray, 2007). This article also challenges traditional gay migration studies in finding that, over their lifetimes, most of our informants do not experience the city as unequivocally "liberating," despite the city's importance in initial development of a gay identity. Therefore, for most (and in particular for older informants) the city is better identified as a transitional space, rather than one which creates or "fixes" these informants' sexual identities. Moreover, if the common process for gay identity development relies on back-and-forth movements between different scales and environments (Knopp, 2006; Knopp and Brown, 2003), both gay subjects' departure from and their return to rural areas need to be more thoroughly documented.

This study first explores the diversity of their life itineraries including various movements between, and within, urban and rural spaces along which participants forge their subjectivity. It 
suggests that even though the city does not stand as a final destination in our participants' life trajectories, experiences in the city play a decisive and complex role in shaping rural gay men's identities. Second, however, for our participants, the city represents simultaneously an attractive and a repulsive space, where sexual identity is both expressed and monitored. Finally, we suggest that how these men construct the country and the city as spaces with prescribed and/or subscribed codes and norms explains their complex but nonetheless decisive feelings toward both spaces and the establishment of their identity as rural gay men.

\section{Methods: Reaching Participant Subjectivity}

One of the major goals of this study was to contribute to the development of theoretical and conceptual knowledge in the field of masculinity in general and rural masculine homosexualities in particular. Therefore, a grounded theory approach was chosen. Grounded theory is a methodology for theory construction where the focus does not lie in hypotheses testing, as it is commonly the case in social research, but on generating a theory from data (Glaser and Strauss, 2006). Grounded theory appears as a set of flexible guidelines aiming to generate a theory that fits closely to the data (Charmaz, 2006). Because masculinity, homosexuality, and rurality are socially constructed, exist in people's consciousness, and are expressed through every day practices, it is methodologically relevant to study them from the subjective point of view of those who live within them (Sasson-Levy, 2002). Our main goal is to allow interpretations of participants' narratives, "to understand the meaning of respondents' experiences and life worlds" (Warren, 2002:84). Therefore, men's sexual and gendered subjectivities can be interrogated in a nuanced manner. Further, to better trace the process of identity and spatial movement, life story interviews were used in this research. A life story 
interview is "the story a person chooses to tell about the life he or she had lived, told as

completely as possible, what the person remembers of it and what he or she wants others to know of it, usually as a result of a guided interview by another" (Atkinson, 2002). Life story interviews give "rich evidence about impersonal and collective processes as well as about subjectivity" (Connell 2005:89). The relevance of life histories rests on the fact that they provide documentation of personal experience and subjectivity as well as an in-depth understanding of social, cultural, and historical structures shaping this personal experience over the life course.

Questions of representation, legitimacy and reflexivity were central to the research process. Kong, Mahoney and Plummer advocate for a "queer methodology" (2002), going beyond traditional "homosexual research" where the subject is perceived as the "other," which reinforces its exclusion and subordination to a hetero-centered regime of power. For this research, we attempted to "queer the interview" in order to avoid the trope of a "coming-out" story as the focal point of research. As necessary, transitions between institutions (such as schools or jobs) were used to prompt respondents' memories, instead of organizing their life story interview around a before- and-after central "coming-out." By doing so, we also aimed at disrupting assumptions of a homogenized experience. However, the centrality of the "coming out" tale was forwarded by the respondents, contradictory to our efforts. Therefore, it is retained in this analysis as it reflects the subjects' self-representation of rural gay male identity and their life trajectories.

We also sought to de-center the traditional relationship of researcher and research subject for this work. Following Bourdieu and Wacquant's (1992) belief that the social location in which the research knowledge is produced and that the social location of the research can impact the interview process, we took particular considerations while collecting data. Interviews took place 
in a location chosen by informants (most often in their home) where they felt comfortable sharing their life narratives. This process places the research subject as an active participant not only in the research, but in the definition of the social location in which the research is produced. Moreover, following La Palestina's (2006) argument that the interviewer's real or perceived sexual orientation might impact data collection and interviewees' response, the interviewer "revealed" his queer identity to informants, both in the context of the interview and in response to direct questioning.

\subsection{Participants: Self-Identified Rural Gay Men}

The informants are 30 self-identified rural gay men -15 of them grew up in the American Midwest, and 15 of them in the Southwest of France. ${ }^{4}$ The men, whose ages ranged from 19 to 62, are mostly white, are working class and middle class, and are involved—at least occasionally—in rural Lesbian, Gay, Bisexual, Transsexual and Queer (LGBTQ) organizations 5 . We reached initial participants by using existing networks of LGBTQ organizations in the American Midwest and in the Southwest of France. This initial sampling was then pursued and completed by snowball and theoretical sampling techniques (Corbin and Strauss, 2007). Data was collected from June 2007 to February 2008 through semi-structured life story interviews. Each interview lasted around 2 hours. As a result of the research design, the research population does not contain men who grew up in rural areas and (1) who have sex with other men but do not

\footnotetext{
${ }^{4}$ The names of all the participants as well as the places where they grew up and currently live are confidential, and all participant names are false. Referring to the participants of this research as "gay men" reflects the way they introduced themselves (they self-identified as gay men and/or homosexual men in the US and as homo, homosexuals, or gays in France). By using this terminology to refer to them, our aim is to respect their choice and not to impose an identity which they might not have chosen.

${ }^{5}$ Our use of the termLGBTQ here reflects how the organizations identify themselves.
} 
identify themselves as gay or (2) who identify themselves as gay but are not involved in existing regional LGBTQ organizations.

\subsection{Rural France and United States as Sites of Inquiry}

The choice of the United States and France was motivated by several reasons. Firstly, despite different distance scales, their rural areas are undergoing similar changes and share common characteristics. They both constitute postindustrial societies where rural spaces can no longer be reduced to agricultural spaces. Rural spaces have undergone significant changes, as have rural populations (Cloke, 2007), yet this increased diversity is not widely reflected in international comparative rural research. Secondly, in both countries, rural spaces are sources of rural romanticisms promoting heterosexuality (Campbell, Bell and Finney, 2006; Saugeres, 2002) and excluding or marginalizing other orientations (Bell, 2006, 2000). Lastly, rural spaces play a significant role in shaping national identity and imaginary both in France (Ageron and Dora, 1997) and in the US (Bunce, 1994).

However, despite these similarities affecting their cultural construction of rural spaces, these two countries present different cultural and political frameworks on sexuality at the societal level. In the French cultural context, sexuality is perceived as a private matter having no space in the public sphere. Whereas in the United States LGBTQ individuals have identified themselves as a "community" and a movement, in France LGBTQ individuals have remained abstract individuals in the public sphere. Inherited from the 1789 revolution, the principle of laïcité plays a decisive role in the French Republic and advocates a well-defined separation between the public and the private sphere. French sociologist Eric Fassin explained that "the separation between the public and the private spheres was $[\ldots]$ intended to prevent the politicization of 
sexuality" (2006:83). French republicanism defines citizens as "abstract individuals" (Johnstone, 2008) whose gender, religion, race or sexuality should not be taken into account. In this context, constructing one's identity in terms of sexual difference goes against the founding of French republican ideals (Johnstone, 2008). As explained by Armbrecht in his provocative article "Can one be gay and French?", "this kind of identity-based politics is known as either communautarism or particularism in France, and is generally seen to be at odds with the universalist ideals upon which the Republic was founded" (2005:20). Therefore, in France, acceptance of differences is believed to lead to the fragmentation of social reality and the breakdown of the social order (Martel, 1999). Consequently, capitalizing on any personal difference in general, and on sexual difference in particular, leads to a threat to the unity of the French Republic. Following this argument, LGBTQ individuals should not privilege their sexuality as source of identity over the universal concept of "Frenchness". These "universalist republican ideals" have been criticized by scholars working on minority issues in the French context for only promoting a model only reflecting White, male, bourgeois, and heterosexual norms (Blidon, 2010; Cervulle and Rees-Roberts, 2010; Tin, 2008). For example, Cervulle and Rees-Roberts (2010) argue that this ideal erases forms of belonging (sexual, religious, ethnic or racial belonging) other than citizenship and mixes national union, Republic uniqueness and uniformity of identity. Hence, it flattens out diversity and, in the context of their studies, denies the reality of French multicultural foundations.

This model contrasts with the American community-based model of social and political collectivities and diverse individualisms. In the United States, individual difference constitutes a principal source of social organization, and identity itself is a political and public force (Calhoun, 1994). Rather than the French republican "universal individual", U.S. culture forwards the 
specificity of identity, establishing links between personal traits, beliefs and/or orientations and the strategic collectivities which emerge along these elements of personal identity (e.g., the civil rights movements in the 1950s, the feminist movement in the 1960s, and the gay and lesbian movement in the 1970s.). American political and cultural movements reflect the diverse and very private nature of identity (e.g., race, ethnicity, sexual orientation, age) which is rejected in the French cultural framework. However, it is important to note that acceptance of difference, while constituting a principal source of social organization within the United States, does not mean that all identities are therefore equal or equally powerful (See Lipsitz, G. How White People Profit from Identity Politics, 2006). For our purposes here, it's important to note that the formation of gay subjectivities and communities occurs within constraints on gay subjects.

Recent studies note how, in order to build a sense a self, rural gay subjects need to negotiate the conservativeness of the social landscape in which they live (see for example, Gray, M. Out in the Country: Youth, Media, and Queer Visibility in Rural America, 2009). Therefore, comparison of the presence of American and French similarities (i.e., hetero-normative rural spaces undergoing similar changes) and differences (i.e., conceptualization of sexuality and sexual identity at the societal and political level) uniquely informs the process by which respondents establish subjective gay identity.

\section{Rural Homosexuality: Studies and Practices}

\subsection{The country in homosexual imaginary}

Social scientists working in the rural field have widely accepted the existence of a "rural idyll" in Western societies in which rural spaces are portrayed as natural and pure spaces, a refuge, away from the corruption of the city (Little and Austin, 1996; Mendras, 1992; 
Vepsalainen and Pitkanen, 2010). In the homosexual literary tradition, this idealized and romanticized representation of the rural also exists. In fact, it has sometimes been portrayed as a safe and eroticized place, another Eden repeatedly referred to as Arcadia (Bell, 2006). In this homosexual tradition, Arcadia is a place in the middle of nature where it is safe to be gay and to freely and publicly express one's gayness (Fone, 1983). Moreover, rural men are sometimes part of this imaginary. Bell (2006) provides the example of the agricultural laborer with whom such qualities as roughness, manliness and earthiness are usually associated. Interviewing gay men from rural Wyoming, Loffreda (2000) showed that several of them actually had experienced brief sexual encounters with urban gay men who came to Wyoming for recreational purposes (mostly to go skiing or hiking) and who wanted to meet "locals" to satisfy their fantasies about rough and manly sex with rural folks. The idea that the rural is a safe and eroticized place, associated with masculine traits such as wildness, roughness, and manliness is also confirmed by Shuttleton's study of writings on gay pastorals. He illustrates that the rural is connected to rough trade and manly love whereas the city is related to effeminacy (Shuttleton, 2000). However, the notion of the rural as masculine and the urban as feminine, suggested here, has to be nuanced as other geographical research shows that the rural landscape has also been portrayed as feminine, particularly in the British context (Little, 2002; Rose, 1993).

Even though rural spaces have been represented in an idealized sexual and erotic way in the homosexual literary tradition, narratives about the experience of gay men growing up in these areas do not necessarily portray rural spaces as the idealized Arcadia. Existing literature about rural male homosexuality (Bell and Valentine, 1995; D'Augelli and Hart, 1987; Kramer, 1995; Loffreda, 2000; Moses and Hawkins, 1980) shows negative aspects associated with life in the country for gay individuals. In fact, rural areas in Western societies remain highly hetero- 
normative spaces emphasizing nuclear (heterosexual) family lives and stereotypical gender roles and interactions which remain unquestioned (Little, 2003; Little and Panelli, 2007). However, as suggested by Bell (2006), this does not mean that there are no possibilities for acting on homosexual desires in the country. Other studies have brought a more complex depiction of gay men's experience (Bonfitto, 1997; Cody and Welch, 1997; Howard,1999; Fellows, 1996; Kirkey and Forsyth, 2001).

\subsection{The issue of isolation and hetero-normativity}

Initial studies focusing on rural homosexuality pointed to isolation as a major issue faced by rural gay men. The first studies on rural homosexuality, which appeared in the 1980s in the fields of psychology and community development (D'Augelli and Hart, 1987; Moses and Hawkins, 1980), emphasized negative impacts associated with rural life. Next to omnipresent homophobia and a pervasive ideology of heterosexism, isolation appeared as a major component of gay individuals' lives in the country. A limited number of gay population results in limited possibilities for networking. As suggested by Moses and Hawkins (1980), this limited population also leads to a lower likelihood that individuals will have anything in common apart from their gayness. This context of heterosexual normativity and homosexual isolation is compounded by the added fear and discomfort about heterosexual people's reaction, pushing rural gay individuals to remain invisible (D'Augelli and Hart, 1987).

Research in the 1990s studying the intersection between masculinity, homosexuality, and rurality in many ways served to reinforce the emphasis on isolation and rural/urban, hetero/homo dualisms (Bell and Valentine 1995; Fellow, 1996; Kramer 1995; Loffreda, 2000). These studies emphasize the experience of isolation that gay men face when living in a rural area. For example, 
Kramer (1995) established the difficulties faced by gay men and lesbians from rural North Dakota in finding a sense of community where they can express their identity freely, without fearing negative reactions from other people. This study underlines the lack of social structures, such as gay bars or bookstores, where they could meet (Kramer, 1995). Looking beyond the brutal events toward the broad implication of Matthew Shepard's story ${ }^{6}$ and based on interviews with gay men who grew up and live in rural areas, Loffreda (2000) provides a deep account of rural gay men's life experiences. Once again, intense isolation appears to be a daily fact that gay men and lesbians have to endure when living in rural Wyoming. The absence of gay bars, bookstores or permanent public gathering places, as noted previously in Kramer's study (1995), increases this profound feeling of isolation. Latent homophobia and a permanent resulting state of guardedness were also mentioned by her respondents. In this context, "policing" the self so as not to deviate too much from the norm becomes an inherent characteristic of gay rural life (Loffreda, 2000:68):

But still you'd lose something of the texture of their lives if you failed to acknowledge the background of calculation, the daily quick math that accompanies gay life, where each act of openness must be weighed against the potential friends, acquaintances, jobs, happiness lost.

Her respondents also mentioned that the Internet had offered them the possibility to find masculine gay role models to help them build their identity. She showed that gay men who grew up in rural settings (on a ranch or in a small town) tend to struggle with the stereotype of gay men as effeminate, a gender identity which they did not recognize in themselves (Loffreda, 2000). Other studies (Cody and Welch, 1997; Fellows, 1996) also note that striving to follow

\footnotetext{
${ }^{6}$ Mathew Shepard was a student at the University of Wyoming, tortured and murdered by two men near Laramie, Wyoming. During the night of October 1998, targeted for his sexual orientation, he was taken into a remote area east of Laramie where he was attached to a fence, severely assaulted, beaten and left to die. His murder brought national and international media attention and led to request for new legislation on hate crimes against LGBTQ individuals in the United States.
} 
traditional forms of masculinity, "butch-ing up" or "cowboy-ing up" (Bell, 2006:170) remain common coping strategies for rural gay men to avoid being perceived as effeminate. Rural places remain overwhelmingly closed environments where traditional hetero-masculinity is pervasive and any deviance from it quickly judged (Campbell, Bell and Finney, 2006).

\subsection{A more complex picture of rural life}

Other studies on rural male homosexuality provide a more complex and nuanced picture of rural life. For instance, studying life experiences of rural gay men in Northern New England, Cody and Welch (1997) identify positive aspects of rural living, despite the continuing issue of isolation. Their respondents note the existence of a quiet, nice and peaceful environment with a slower and less stressful pace of life, as well as the creation of networks of intimacy or a small group of close friends (not necessarily gay) with whom one can socialize and find social support. Therefore, Cody and Welch conclude that even if the negative aspects of rural life exist and should not be discounted, positive aspects also exist for rural gay men which establish the rural space as desirable: "It [life in the country for gay men] is not as idyllic as Whitman's Leaves of Grass implies; however, neither is it as abyssal as urban gay folklore currently suggests" (1997:64).

This simultaneous presence of positive and negative aspects associated with living in a rural setting is reflected in a series of studies in other regions in the United States: Fellows in the American Midwest (1996); Bonfitto in New England (1997); Howard in rural Mississippi (1999); and Forsyth in Massachusetts (1997, 2001). In Farm Boys: Lives of Gay Men from the Rural Midwest, Fellows (1996) argues that if isolation constituted a central component of the life experiences of his respondents, it was also a saving experience for many of them. He found that 
"isolation hindered and helped them in coming to recognize and understand their differences," by helping them to avoid "the potentially devastating expectations and ridicule of their other peers" (1996:13). If growing up on a farm did not provide information about sexuality in general and homosexuality in particular (due mainly to religious conservatism and sexual prudishness), it facilitated farm boys' escape from pressure to conform to standards of masculinity. Living on a farm also helped these boys to "invent themselves according to their inclination and standards" (1996:16) and kept them away from constant teasing from other boys. The work of Forsyth (1997, 2001; also Kirkey and Forsyth, 2001) also challenges the idea that homosexual desires do not exist in rural places and that developing a sense of gay community is not possible. Looking at life experiences of gay individuals in the Connecticut River Valley of Massachusetts, she showed that in this area, comprised of rural towns, a gay male culture had formed and was highly visible and strongly integrated into the larger community.

\subsection{Rural to urban migration}

However, despite the complications present in research introducing negative and positive aspects of the rural landscape, much of the existing literature on gay migration has emphasized

departure from the country (generally portrayed as unsuitable to gay lifestyles) to the city (represented as the land of promise). Gay migration studies have consistently stressed the importance of the perceived symbolic binary rural/urban categories in understanding relocations of gay individuals (Binnie, 2004; Brown, 2000; Cant, 1997; Chauncey, 1994; Rubin, 1993). As a whole, these studies suggest that rural gay men caught in hetero-normative cultures needed spatial displacement and relocation to urban spaces in order to be able to "be" gay (Blidon, 2008; Rubin, 1993; Valentine and Skelton, 2003; Weston, 1995). In this body of work, "large cities are 
often understood as sites of homosexual freedom, affirmation, and inclusivity and places where same-sex desires can be enacted openly" (Johnston and Longhurst 2010: 105). Thus, these studies conflated gay migration with rural-urban displacement where rural areas were portrayed as inhospitable places for homosexual sexuality in contrast to urban spaces which were portrayed as idealized places for homosexual practices. Rubin (1993) argued that these ideas were developed following the emergence of urban communities during the end of the 19th and the beginning of 20th centuries in North American and European cities. She explained that since the birth of these urban gay communities, urban centers have been described discursively as places imbued with tolerance of alternative sexualities. In his historical sketch about the relationship between homosexuality and the city, Aldrich explained (2004:1719):

Homosexuals often moved to cities to escape the sexual and social constraints of traditional life, and they played a major role in transforming the city and in creating a particular urban ethos. The city, in return, is the site for the construction of much contemporary gay and lesbian culture.

The association between homosexuality and the city has become so widespread in Western culture that the rural-urban distinction has become embedded in gay consciousness (Binnie, 2004; Johnston and Longhurst, 2010). Parallels between socio-psychological and geographical itineraries have been drawn in which isolated and lonely rural gay men move to urban centers to explore their same-sex desires and come to feel part of a community in the urban space (Eribon, 1999). However, these works about gay migration from urban places to rural places have recently been challenged. However these works about gay migration from urban places to urban places have recently been challenged by Gorman-Murray (2007) for not considering the complexity of the reality. He suggests that the conflation between gay migration and rural-urban migration is simplistic and only gives a partial view and understanding of gay 
movements. Firstly, he argues that these works (all stemming from research in Western postindustrial societies) only focus on gay migration from rural to urban, thereby missing the majority of gay migrations. Part of this obscuration is simply demographic. In these societies most of the gay population is urban, as is the rest of the population regardless of their sexual orientation. Thus gay migrations are more likely to occur from urban spaces to other urban spaces rather than from rural spaces to urban spaces. By equating gay migration with rural to urban migration, gay migration studies only account for a small portion of gay individuals' experiences. Secondly, "the concentration on the rural-to-urban trajectory suggests a teleological finality with respect to displacement and ontological closure with regard to identity" (GormanMurray, 2007: 109). Further he argues that "this unidirectional rural-to-urban movement intimates a once- and-for-all emergence from the rural 'closet,' and the assumption of an already-fully-formed and fixed urban queer identity" (Gorman-Murray, 2007:109). Here, he criticizes gay migration studies for assuming the impossibility of developing a gay identity in rural areas, and the necessity of going to urban centers to develop one. Also, he points out that gay migration studies mistakenly assume the existence of a unique, "fully-formed and fixed" identity in urban centers. As an alternative, Gorman-Murray advocates for a queer approach to gay migration studies - a multidirectional approach, with possible returns, movement from rural areas to other rural areas as well as movement from urban areas to other urban areas. He defends the idea that this approach to gay identity should not be seen as static but should be conceptualized in a way that leaves possibility for changes, evolutions, and questions (GormanMurray, 2007).

Other studies focusing on life experiences of gay men and lesbians individuals in rural areas have suggested possible stays, or return, to the country. For example, Fellows (1996) 
shows that not all gay men and lesbian women born and raised in the country decided to move to the city, despite his retention of the rural-urban binary. Some of them stayed in the country and lived a life of openly gay individuals. Moreover, especially in the Western world, the countryside has frequently been portrayed as a place of refuge away from the corruption of the city (Johnston and Longhurst, 2010). In this context gay individuals have moved to the country to create radical communities, such as for example the radical faeries, advocating for an alternative lifestyle in the middle of an idealized space perceived as pure and natural (Bell, 2000; Valentine, 1997). However, not only radical gays choose to move to the country; gay individuals with more "middle-class concerns" have also left urban spaces to enjoy rural amenities. Works from Kirkey and Forsyth (2001) in the United States, Smith and Holt (2005) in the United Kingdom, and Gorman-Murray, Waitt and Gibson (2008) in Australia describe the public presence of gay\& communities in rural places. This set of studies depicts gay communities in rural areas as committed to home-centered ways of life and as integrated into the larger rural community surrounding them.

Although this recent literature indicates that gay individual's migration patterns do not necessarily follow a unidirectional path from the country to the city, further documentation is needed. Gay migration is still widely socially perceived and academically conceptualized as unidirectional, from the country to the city (Johnston and Longhurst, 2010). In this context, our research provides empirical evidence of the complexity of rural gay men's movement between the country and the city. It gives an account of real life experiences of rural gay men by focusing on their process of identification through their displacements between these two spaces. The following section presents the migration stories of four participants which outline these 
multidirectional body movements from the country to the city and their importance in our informants' construction of both their rural and homosexual identities.

\section{The City and Rural Gay Migration: Four Life Stories}

Results show that variations in life histories and itineraries are more significant within each country than between countries. Emerging patterns suggest that due to growing up in the country informants experienced difficulties to "fit in." Yet, respondents also mentioned the lack of role models to build their identities. In this way, these stories reinforce previous studies indicating that the city appears as the place for the exploration of same-sex desires and attractions and holds a major role in rural gay men's identification process. The four life stories presented in this section, from two French and two American informants, reflect the diversity of observed movement in all informants' life itineraries. Thus they provide a representative portrayal showing the importance of body movement between the country and the city, and the significance of the city in the identity construction process of our informants. However, these life stories also demonstrate complexity in the evolution of rural gay identity and their final location.

\subsection{The story of Dan: from a small town, to a college town, to a city}

Dan is an openly gay American college student in his late teens. When this interview took place he was living in a town of 20,000 where he attended college. He grew up in a small rural town (less than 1,800 inhabitants) in the Upper Midwest located a little more than an hour away from a larger metropolitan center of more than 100,000 inhabitants. Growing up he felt physically and emotionally attracted to other boys. Not being able to make sense of these feelings, he felt lost and isolated. Clearly, for him, these feelings were not part of the social 
norms existing in the rural town in which he was living. At 13, often chatting on the web with people from other areas, he learned about homosexuality and was then able to put a name on his feelings. At 16, he was regularly driving to a bookstore located in the nearby metropolitan center to read books, mainly novels, dealing with gay characters. Prior to attending college, he came out to his family and friends - at the time he was still in his senior year in high school in a nearby town of 2,500 inhabitants.

Shortly after this interview took place he moved to a bigger city (90,000 inhabitants) in the Upper Midwest region to complete his bachelor's degree. He moved because he felt oppressed by the conservatism of his rural community and of the college town. Despite being out to his family and friends, he felt that the environment he was living in constituted too much of a strong constraint to fully express himself and his identity, and limited his ability to have an open relationship with another men without public judgment. Moreover, he found it difficult to find other gay men with whom he could relate, as the men he knew from college were "either too conservative or closeted". Hence he moved to a nearby city, a place he sees as having "more people who are more open and with different mentalities," a place where he could find gay men with whom he could relate. For Dan, at this point in his life, the promised freedom of the city is exemplified.

\subsection{The story of Jean-Pierre: moving to a large city and coming back to the country}

Jean-Pierre is a 38 year old openly gay man who grew up in the Southwest of France on a small family farm located a little more than an hour from a large city - a place that neither he nor his three siblings ever visited. As a pre-teen, he started experiencing desires and attractions for males. Not knowing about homosexuality, but clearly understanding that being a boy and feeling 
attracted to other boys was not the norm, he kept his feelings quiet. After completing primary and secondary schooling, he went to a vocational school located in the very close suburban outskirts of the large city. There, from his school peers who were coming from diverse backgrounds—not necessarily rural — he learned about homosexuality, its meaning, and its discredited nature. At this time, he witnessed other male teenagers being ostracized by peers for being effeminate, a feature that he and his peers conflated with being gay. Although he thought that he was gay, he did not want to accept it. Although he thought he was gay, he did not want to accept it. Consequently he tried to erase any feminine behaviors so as not to be identified as being gay.

After graduating, he did not want to move back to the rural area in which he grew up. $\mathrm{He}$ took a job in the Recreational Department of the large city to take care of public gardens. He believed he could explore his same-sex desires and attractions only there, in the anonymity and openness of the city. He started buying gay magazines from which he learned about gay bars, saunas, and clubs, and there had his first same-sex sexual encounters.

After nine years working in the city and being part of the gay community, he came out to his family. He eventually found a partner who had spent his entire life in this city. Together they first moved to a suburban neighborhood, and after four years, they decided to move back to a rural town. They chose to do so in order to escape the "craziness" of the city (as he phrased it) and to enjoy the quietness and the preserved environment of rural areas. His attitude toward the "freedom" originally perceived in being part of a gay community too had changed. At the time they decided to move, he was no longer involved in the gay community as he believed it was "too superficial, too much focused on having fun and brief sexual encounters", practices which, 
to him, give a negative image of homosexuality. For Jean-Pierre, the city served a function in identity development, but was far from the life which he desired.

\subsection{The story of Ronald: staying in a rural town but going to the city to explore gay life}

Ronald is an American gay man, in his early 60s at the time of the interview, who grew up on a farm in the Midwest. Currently he works as a research associate in a public institution located in the same state where he grew up. For much of his life, Ronald was only out to his close (gay) friends. His recent involvement in LGBTQ activism established his identity as a gay man in his community. Growing up on a farm, the closest urban center (with around 75,000 inhabitants) was a two-hour car drive distant. While attending middle school and high school in nearby rural towns (less than 1,500 inhabitants and 30-minute car drives from his farm) he felt lonely and did not have a lot of friends. He was ostracized by other boys because he was not "fitting in" and was seen as different for not following traditional gender roles. He did not identify himself as being gay, as he did not know anything about homosexuality, but felt disturbed as he was experiencing same-sex desires and attractions. Being a good student, his parents encouraged him to go to a university. At the end of the 1960s, he moved to a college town in the same state, where he still lives today. The predominance of rural space in the state and the presence of the university establish this town as a significant urban center, despite having only around 20,000 residents. During his first years of college he was called a "homo" by other male college students. Curious about the term, he did some research at the library whose size (the biggest one in the entire state) allowed for the presence of diverse resources on various topics, including sexuality. Through this research, he learned what homosexuality was, but refused to identify himself as being gay. At the end of college he eventually came to terms with his 
sexuality because he realized that he could not change. Until this point he never had any sexual experiences.

After finding a job in the college town, he took a trip to a large metropolitan center on the East coast, where he could meet members of the gay community and "release" his same-sex desires and attractions. He felt strongly that his sexuality could be expressed "only there", and not in his hometown. He explored the city, ended up buying a city guide which highlighted gay bars, movie theaters and clubs. Shortly after his arrival in the city, he met another man in a gay movie theater and they had sex in his hotel bedroom. Feeling that he had just been "used" as a sexual object by someone who had more same-sex experiences, he felt disappointed and decided to leave the city. Since then, he has been living in the same college town and working at the same institution. Regularly, he has been back to large metropolitan centers on the East and the West coasts to experience the gay urban lifestyle. Recently, he has become more involved in local LGBTQ groups and has been able to find a sense of gay community. For Ronald, visiting the city was and is pivotal to his sexual identity and his expression of it, yet not entirely perceived as a desirable place in which to live his daily life.

\subsection{The story of Michael: moving from a provincial city to a rural town, with a short stay in the}

\section{French 'gay mecca'}

Michael is a 27 year old French self-identified gay man who currently lives with his partner in a coastal town of less than 3000 inhabitants. He grew up in the Southwest of France, in a mountainous village of 300 inhabitants located 45 kilometers away from a city of 80,000 inhabitants. The only boy of four siblings, he grew up with all the attention of his sisters and parents. All of them were very protective, seeing in him as the family "heir," the only one who 
would transmit the family name. Throughout his childhood and teen years, he remained unaware of what homosexuality was. Although he recalls regularly being called a "pédé" ("faggot") by his male peers, apart from recognizing the derogatory nature of the term he was not aware of its meaning.

When he started experiencing desires and attraction for men, he could not make sense of these feelings. At age 16, having just received a motorcycle, he was able to drive to the nearby city where nobody would recognize him to buy heterosexual porn movies. Realizing that he was more attracted to male bodies than female ones, he started buying gay porn movies. Through these movies, he discovered the existence of homosexuality, the homosexual subject, and started identifying himself as a gay man. At age 18, he decided to quit his training as a plumber-a profession that his parents had chosen for him - and moved to the nearby city where he took a job as a waiter. There, he experienced his first same-sex sexual encounters, but was still not openly gay.

When he was 19, he took some vacation time in Paris to discover the "gay urban lifestyle”. Staying in Le Marais, the Parisian gay district, he went to gay bookshops, bars, nightclubs, and felt overwhelmed by how easy "being gay" seemed to be. He bought new clothes, dyed his hair, and went back to his waiter job in the provincial city in which he lived. Changed physically and having been exposed to openly gay men, he came out to his family and friends. He faced strong disapproval from his parents and sisters, who stopped talking to him. He decided to move to a rural town (less than 3,000 inhabitants) along the Atlantic Ocean, located more than one hour away from the closest metropolitan center. Michael chose this rural environment because he felt that social relationships were more sincere in this context and that finding a sense of community (not necessarily a gay community) would be easier. Once there, he 
took another job as a waiter, but changed his presentation of self to a more conventional one (or as he said, "looking like any other guys"). He thought that during his time in the city, he had become superficial and placed too much emphasis on physical appearance. He created a LGBTQ organization to offer a place of social gathering for LGBTQ individuals living in the surrounding area. For Michael, the city provided a necessary social and political understanding of his sexual identity but was not a valued place in which to live those newly found ideals.

These four life histories give a representative portrayal of emerging patterns echoed in both France and the United States. While it is true for all that the city provided the opportunity to be sexually active, and stood in stark contrast to (in particular) the conservatism of rural spaces, three out of four continued to live in rural spaces, and did so because of a rejection of sorts of the city. In these stories, the city stands for a space that one has to experience in order to make sense of his same-sex desires, a "must-go-through" space. Growing up isolated, out of place and with a lack of role models in the country, these men tend to idealize the city - a space they had not experienced. Once experienced, however, all but Dan (the youngest) changed their representation of the city and its place in their lives and identity.

It is also important to note, however that mobility practices characterize modern societies (Knopp, 2006). Voluntary migration is mainly experienced by those having the social, cultural, and/or economic means of being physically mobile. Belonging to the working or the middle classes, having no strong family attachments or commitments, or pursuing an education allowed both French and American participants to be mobile. Their experience of the city ranges from short stays to longer and possibly definitive ones. However, these life itineraries reveal that informants do not necessarily remain there and a return to rural areas is both possible and 
preferred. While echoing the importance of the city for sexual identity development, speaking about unidirectional movements from the country to the city clearly simplifies rural gay men's experiences and desires. As these stories make clear, deliberate repeated movement from the country to the city and, often, back to the country reflects more clearly the reality of their lives.

\section{The Ambivalent Call of the City}

In order to understand these back-and-forth movements in their life itinerary, we turn now to broader exploration of what meanings, images, and representations rural gay men in this study attach to the country and to the city. Our findings suggest that, for them, the city represents a space with both attractive and repulsive sides explaining their desire to experience the city but not necessarily a desire to remain there.

\subsection{The city as a gay 'mecca'?}

Existing literature points to the representation of the city as an idealized space allowing the free expression of non-heterosexual identities (Blidon, 2008; Cant, 1997; Chauncey, 1994; Weston, 1995). In our participants' imaginary, particularly when they are at a stage of their life when they have not yet left the country, the city also stands for a gay "mecca" where it is safe to be gay and to express freely one's gayness. For all rural gay men interviewed cities appear as places with distinctive characteristics constructed in opposition to the country. In this way, rural gay men themselves often perpetuate the rural-urban dualism.

For gay men who grew up in the American rural Midwest, the city appears in the rural gay imaginary as a way out of the oppressive environment encountered in rural areas, as already noted in the literature. To these men, rural areas are mostly seen as homogeneous with a 
significant lack of diversity. Reflecting on the place where he grew up (a country town of approximately 850 inhabitants), Marcus, a self-identified gay man of 26 explained:

Here, there are a lot of farms around. If you go outside of town in any direction, it's fields. It's very low pace. In [name of nearby city], there's more diversity. Here people are predominantly German, Norwegian, or Dutch. If somebody does not belong to the same type of church that the majority belongs to, people would talk about it. They would criticize. It was small and friendly, but at the same time, it was fairly uniform.

As noted by Marcus, rural areas can be felt as restrictive due to the rules of conformity and also sometimes oppressive because everyone knows each other. The city is constructed as the opposite. Following previous findings (Chauncey, 1994; Valentine and Skelton, 2003), in this study, interviewees perceive the city's racial, cultural, and social diversity as an important feature contributing to openness for different lifestyles in general, and for the gay lifestyle in particular. According to American informants, this appealing side of the city is due to its allowance for more anonymity, something not possible in the country. The city gives the possibility to separate one's professional and private lives, and to have two or more distinct and separate social identities (e.g. professional, religious, sexual). Therefore, one can remain "in the closet" at work but openly express his same-sex desires outside his professional environment.

When questioned about differences between rural and urban life, Ronald, who resides in the rural college town but still frequents the city, identifies these advantages as related to life in the city:

In urban areas, gay men have more opportunities, a lot more opportunities to be themselves, to be open about themselves, because in an urban area there is a gay culture. It is easier to be open. One might not be open at work, but he might be open in other social contexts, and, of course, there are more opportunities to meet others, and to be involved. If you want to be open in a rural area, as I said, for some people it works, for others it does not work. In rural areas, it is more difficult to meet people, if you want to get together with friends, somebody has to travel. Social gatherings happen but you have to make an effort to find them and to go to them. 
In addition to pointing out perceived advantages associated with urban life, this quotation stresses the proximity of a gay community. For rural gay men, a significant positive feature of the city is the existence of an identified gay community with specific and easy-to-locate gay spaces - such as gay bars and clubs-where gay life takes place. After growing up in an environment where most of them felt they were the only gay individuals, discovering the existence of a gay culture is a freeing experience for them. Christopher, a young man who currently lives and works in the rural community where he grew up, recognizes that "for years I thought I was the only one," and that "most people in rural areas tend to think they are alone and they run away to the big city." One of the first things that rural gay men do upon arrival in the city is to look for these easily identified gay spaces to meet other gay men and to discover and experience gay life in order to become "gay."

Moving permanently to the city has crossed the mind of all gay men interviewed —all of them have been to the city temporarily. Their past experiences and current practices range from having sporadic excursions in urban gay spaces to experience the gay "lifestyle", to staying and working in the city for several years. For the vast majority of our informants, moving to the city became a major objective, for some even an obsession. Throughout high school, when dealing with his same-sex attraction and desire, Sam kept on fantasizing about life in the city:

After high school I came here [rural college town], and it was so weird because during my senior year in high school I kept telling myself "I have got to deal with this, I have got to come out, I have got to..." I don't know why but I had this fantasy, I wanted to move to a big city and there I would be happy, I would find people that would be accepting of it and I would be fine...

Contrary to the country, which is seen as oppressive and constraining to the development of a gay identity, the city gives the opportunity to develop this identity. It is what Marc, a young man who grew up in a rural town and moved to a city to study and work, stated bluntly: "I went 
to a large urban area to develop my gay identity." It is only when he arrived in the city that he was able to start exploring his same-sex desires and attractions which was for him not possible and unthinkable when he was living in a small rural town:

The advantage has been very much so that somebody who came from somewhere where there was no gayness and in college still being repressed and suddenly being dropped into the middle of a gay ghetto where I was having sex all the time. I was so skanky, it was terrible! I got my first STD when I was establishing my sexual identity, thank God it was not too serious. I never had unsafe sex but it was just, you know. . . It was just this nonchalance about sexuality, being free, to be one self, but at times it was just too much.

Marc's experience also shows that moving to a city and being suddenly exposed to a gay community is an overwhelming experience for many of these men. Because of the ease of finding gay spaces, these rural gay men found it easier to meet other gay men and role models from whom they can take examples to build their identity and start "being" gay and "acting" gay. However, the ease of "being" and "acting" gay were also noted as points where some of these men felt they were both gaining and losing their identities. While enjoying their freedom and actively building a gay identity, some of these men, like Michael in the previous section, were also critical of the gay urban identity and its expression in urban culture.

For French research participants, the city is appealing as it is also perceived as a place where it is easier to be gay and live one's homosexuality. For them, the city offers more opportunities for social gathering between gay men and also for cultural activities. Contrary to the country where everyone knows each other, in the city, they assume that the anonymity resulting from the larger population makes life easier for gay men. Contrasting his experience living in a large metropolitan center after growing up in a village of 650 inhabitants, Yannick, a French man in his late 20s, explained:

It's different from the city because of the close-mindedness on certain issues, and also the fear of others' opinion. In the country, there are fewer inhabitants, you know anything 
you say is going to spread in an afternoon. There's always this fear, this pressure... There's a very strong pressure on your private life, because you know that everybody is going to be aware of it. In the city...it's not that there are no bonds between people, but you just don't give a shit of what your neighbor does! Not in the country.

Like their American counterparts, French rural gay men feel that in the urban space it is possible for gay men to "disappear" into the crowd, a feat not possible in a small town or a village. In the majority of the interviews, rural space appears more as heterosexual space where homosexuality is pretty much invisible, whereas urban space is a more cosmopolitan space, with a more visible gay population. They are drawn to the city due to the presence of a visible number of gay men, but also due to the invisibility of an individual gay man. In the country, they fear the visibility of an individual gay man due to the invisibility of the group.

In some cases, homosexuality and urbanity are even perceived as complementary and related. When asked about differences between him and other men from the village where he grew up, Thierry, a young gay man studying in a large city in the Southwest of France, declared that apart from his sexuality, the fact that now he is more a "city guy" is the only difference. $\mathrm{He}$ then added that "homosexuality" and "being a city guy" are related.

Beyond merely being a place where it is possible to explore one's same-sex attractions and desires, for the French participants, the city was also presented as the only place where it is possible to come to terms with these attractions and desires. Yannick-already mentioned earlier—said:

I really came to terms with my sexuality when... when I turned 18 , when I was able to go out. I was then able to have my own car to leave the country to go to [name of a nearby large city] and go out in the gay milieu.

According to Yannick, being in the country stopped him from exploring his same-sex desires and attractions, whereas by going to a city, he was able to do so. Like their American 
counterparts, going to an urban center becomes a necessary rite of passage that one has to undertake, and in some cases, going through this rite of passage can become an obsession. Still speaking about his strong desire to go to a city, Yannick mentioned later in the interview:

Fucking hell, actually it was like an obsession. I worked all summer long to be able to buy me a car and my only goal was to take the car to go out. It was very stressful, you know, because you don't know where you are going, I was just leaving the place where I grew up, and then you discover your first gay club.

Growing up in the country and during their adolescence, both American and French participants tend to construct the city in opposition to the country. They perceive rural spaces as "homosexual vacuums" where homosexuality is left undefined and where the acquisition of a gay identity remains impossible. As already stressed by existing literature on rural masculine homosexuality (D'Augelli and Hart, 1987; Kramer, 1995; Loffreda, 2000; Moses and Hawkins, 1980), they emphasize rural isolation, homogeneity, conservatism and hetero-normativity as major components of their lives. In contrast, they conceptualize the city as an idealized space where diversity, anonymity and a supportive gay community exist. In this space, they can move their attractions and desires into practice (Weston, 1995) and actively develop their gay identity. Therefore, in both American and French participants' imaginary, the city stands for a place of sexual freedom (Aldrich, 2004; Binnie, 2004; Johnston and Longhurst, 2010). Echoing findings from Valentine and Skelton (2003), the existence of a gay scene with a gay community and easily identified gay spaces (bars, bookstores, clubs) give our research participants an alternative gay cultural framework where they can express their identity, and have this identity validated by others. In this way, they are able to negotiate both becoming visible as members of a group while remaining invisible as individual gay men thereby excluding themselves from the judgment of the rural communities from which they come. 


\subsection{The Dark Side of the City}

However, as suggested by the previously described life itineraries, the city does not stand as an end point in informants' life itineraries. While the city appears as a very attractive place for our research participants, as noted in the previous quotes its significance is far more complex.

The ambivalent relationship that these men entertain with the city in general, and its attached gay scene in particular, was suggested by Valentine and Skelton (2003). Their study points out the paradoxical role of the gay scene which provides the freedom to explore sexual identity but which may also "precipitate a forced transition to a lesbian or gay sexual identity" (Valentine and Skelton, 2003:857). In our study, both French and American interviewees also associate negative aspects with the city and the gay scene, which they perceive, at least initially, as completely imbricated. Entering an urban gay space, no matter how strongly they have fantasized the first step in this "dream" world, can be problematic for rural gay men. Being able to go to an identified gay space in a city — a bar, a club, a sauna, a cruising area, or simply a gay district—is, at the same time, an exciting, liberating and intriguing experience and a stressful one. The anxiety that they experience comes from their ignorance of the implied codes that regulate these spaces and their unfamiliarity with the "gay scene." When Michel, a single closeted gay farmer in his early 50s living on a farm with his parents, decided to explore samesex encounters 30 years ago, he went to a cruising area located in a small city 10 kilometers from his farm. Once there he took some time to observe men's behavior as he did not know what to do:

So I decided on an impulse to go to this cruising area in this nearby city. It was a gay cruising area next to the river, but now it does not exist anymore. So I went there, I parked my car, but I did not know how to proceed. So, first, I started observing what the 
guys were up to. They were going back and forth, all of a sudden, one came to me, he was cute, and he started talking to me.

Yannick, the young gay man in his mid-20s who was eager to get a car to be able to go to a gay club in a nearby city, describes the oppression he felt:

I took my car one night, I went there [a gay club in a large city] and I stayed there for one hour at the most! I literally ran out of the place, really, I was like. . .you know, I swear, I had never felt that oppressed before than when I entered in the club. First coming in...there was...you know, there was a man, he was the very effeminate type. So first, I thought: "oh, great," It was really strange to me, and then I started feeling better... but the thing is that I arrived too early, there were not many people, I was not comfortable, you know. . . I was really stressed you know, and after one hour I left but I was happy I did this first step. I told myself that at least I was able to do it, and later on I went back.

This apprehension seems to stem from their ignorance of the rules of behavior and interaction, even as they seek to affirm and accept their attractions and desires for the same sex. However, this same individual freedom means accepting homosexuality as a source of identity. Some gay men (from both nationalities) never had the courage of entering these spaces because they were not able to come to terms with their sexuality or they were not ready to face a subculture they had not been exposed to before. In the account of his life story, Christopher, an American participant, describes the hesitation he felt when moving from a farming community to a 150,000-inhabitant town in the same region:

I came out when I was 25. I had move to [name of the city] in 2001 when I was 21,22 . I wanted to move there to run away to the big city. This is not a big city but when you come from a town of 200, it is a big city. I had some friends up here, so I just thought it was something different. A position came up within the company to transfer here. I was just one and a half hour away from home. I lived in an apartment, and I remember that there was a gay guy living in the next building over. I remember that when I learned that there was a gay guy, I wanted to find him. Of course, when I found out who he was, I got scared and could not talk to him. Then, there is a gay bar downtown, and I can remember sitting in my car and I could not go in. Scared of what I was going to see, scared that somebody I knew was going to see me. So I just relegated myself to stay in my apartment, and then I had some friends there. 
First, Christopher's account illustrates once again the desire expressed by most rural gay men to "run away" to the city, where they assume life will be easier for them because of their sexual desires and attractions. Once he arrived in the fantasized city, he looked for other gay men he could relate to and for gay spaces he could socialize in and explore his sexual desires. He was unable to fulfill any of these dreams, however, because of his fear of not knowing the codes, and because talking with his gay neighbor or entering the gay bar would have meant being perceived as a gay man by others. That full recreation of his identity is what he was not ready to accept. After spending two years in the city and parking next to its only gay bar several times without ever being able to go in, he decided to move back to his rural community.

"Getting to the big city" can therefore become an overwhelming experience. In fact as explained by Knopp, "queer migrants to large metropolitan areas...do not arrive as tabula rasa when it comes to their various forms of resistance," on the contrary "they bring with them world views, values, traditions, memories and experiences...” (2003:422). Both American and French participants stressed the fact that they grew up in rural places where homosexual lifestyles were invisible. Consequently, the learning of norms and codes governing the urban gay scene was challenging for men who have grown up isolated in a hetero-normative space, and, in some instances, went against the value systems they had developed growing up in the country. However, while both American and French participants tended to associate negative features to life in the city, their reasons slightly vary.

For American informants, urban gay life and the urban gay community are often perceived as superficial, giving too much emphasis on short-lived sexual encounters and physical appearance such as clothing and haircuts. Further, this superficiality both complicated and challenged their attempts to create themselves as "gay men" in contrast to their rural background. 
When Marc explained how he felt overwhelmed by a feeling of sexual freedom when he moved to the city, he also admits that "it was just too much." Today, living in the rural town he grew up in and helping his parents manage two family restaurants, he reflects on his past life in the city and does not regret it:

I actually do not miss [name of the city] and the gay life style. It was actually getting on my nerves. I mean, I enjoyed going to the gym but it was increasingly becoming like a chore, like I had to budget my time for the gym every day. Here I don't worry about that at all. I am just out of shape now, but it was just like an extreme, going to one extreme to another. Here, what I am glad for is that I now have the knowledge and the understanding that there is another world out there that is technically waiting. I can go back to that and just fit in whereas before when I was first introduced to it, I was completely blind, I did not have anybody to guide me, I saw all this attractiveness and underneath I did not really understand how many of them were really insecure, like anybody they had their own story, but when you are fresh in there and you see all of this you are amazed. Now I am much more realistic.

Here, Marc points to the superficiality of his lifestyle in the city and the pressure that goes with living within a gay urban community. He echoes Valentine and Skelton's (2003) findings regarding the pressure to conform to a particular hegemonic gay masculine identity in the urban gay scene. However, Marc does not completely reject the urban gay community. For him, knowing it is "out there" seems to be reassuring, knowing that he is not the "only one," and knowing that whenever he wants to he can go back to the city and be part of the gay community. John's testimony also points to the ambivalent role of the city for rural gay men. In the 1960s, after spending his childhood and teenage years in small rural towns of the upper Midwest, he went to a large city in the American West to start vocational school, and to run away from the pressures he had experienced until then: "The fall I graduated from high school I moved to [name of city] to escape and to go to vocational school. I wanted to be an architect." Soon he started to look for a gay life and other gay men: 
When I started venturing around [the city], I learned at that point where the gay bars were, and where the gay guys hanged out, so I started going to those places, started meeting guys, so it would be at that point, I was in my early 20s, that I had my first intimate relationship. There was still a lot of alcohol involved, but it was more than playing around. It felt like love to me. It is what I thought love would be or should be. We cared about each other, and had no qualms about being real close and holding and touching, playing around, experimenting.

However, today, when he reflects on his first experiences in the gay community he points to its superficiality:

So I dropped out of vocational school, I got a job as a waiter, earned very very good money, started going to the gay bars a lot, buy all kinds of clothing, started to fall into the whole routine of being a young gay men and trying to be attractive, paying a lot of money for haircuts and hair styles, and clothes, even having a degree of competition with a couple of other guys that I knew from the bars, showing up in the bars with the most recent fashion, and all this silliness that takes so much time.

While here the city is identified as a place with a gay life and a gay community, where it is easier to disappear, John recognizes that anonymity also brings impersonality. For both Marc and John, while the city provided the public space for expression of their gay identity, it also dictated the parameters and constraints of that identity in unexpected and ultimately uncomfortable ways. Indeed, in this study all American informants emphasize the perceived the existence of pressure to conform to a particular hegemonic gay masculine identity mainly based on body image and appearance.

For French study participants, the city also has a complex and paradoxical meaning, however one which conflicted with their conceptions of masculinity rather than the critical view of superficiality expressed by their American counterparts. For these men, the perceived effeminacy of the urban gay community proved the greatest obstacle to involvement and identification with the urban gay identity. Michael describes this ambivalence in the perception 
of the city. On the one hand, living in the city makes it easier to be gay and to accept one's homosexuality, but on the other hand, living in the city leads to effeminacy:

I think if I would have grown up in a city, I would have come to term with my sexuality earlier, but I would have become a queen. When I went to Paris, I came back looking like a queen. I think that if I had grown up in a city, I would have become an effeminate gay man.

The perceived deterministic nature of the city appears clearly in this comment. According to Michael, the city "makes you" effeminate, and being an effeminate gay man is something unacceptable in his eyes. For him, it does not reflect how he sees himself — as a man like any other-and it does not reflect rural gay men's experience. Later in the interview he said:

That's why we created an organization in this small town, so that people in the country know what homosexuality is. Showing that homosexuality is not only about queens and effeminate gay men, homosexuals are individuals like anybody else, individuals working in factories, working in fields, everywhere. . showing them that perhaps in their surroundings there are gay people, showing them that we don't all live in cities, showing them that in the country, too, there are gay men and that we all have the same need.

For Michael, there is a need first to bring homosexuality to the forefront of rural life where it has been ignored. Second there is a need to educate rural people in order to show them that there is another side to homosexuality — of course a good and respectable side — which is not about being effeminate, but about being manly "like anybody else." But who is "anybody else?" It is interesting to note that to these French rural gay men being "like anybody else" is to be working in factories and in the fields, two overtly perceived masculine activities. "Being like anybody else" can be restated then as "being like any other masculine and heterosexual rural man." These men emphasize the masculine and heterosexual nature of rural space. They create the city along this same dualism, the city is a more cosmopolitan space where expression of 
nonconventional identities is possible but not desirable because it creates a perceived conflict between their gender and sexual identities.

Eribon (1999) notes that, throughout the 20th century, in French popular culture and homophobic discourses, gay men were constantly caricatured as effeminate men. The figure of "la folle" was central to this system of representation and gay men portrayed with feminine features. Consequently, Le Talec (2009) argues, French gay men struggled with this imposed cultural representation. In complementary fashion, in this study French informants associated effeminacy and the city. They sustain a deterministic discourse regarding the role of the city in shaping gay men's identity. By going to the city, being part of the gay community and exploring one's same-sex attractions and desires, they feel that their identity is being altered rather than freely expressed. Alterations and transformations are performed to reflect norms existing in the urban gay community, especially in relationship to what seems to be appropriate regarding physical appearance. Speaking about coming out to his mother, Michael explained:

[When] I told my mum, I was just coming back from my trip to Paris. I had been to several European cities, but Paris...it was my first vacation on my own. I stayed near the gay district, so I discovered all the places and I came back with an entire different look. I dyed my hair, I was wearing tight clothes, I was the perfect queen!

Getting rid of one's old (rural) physical appearance and adopting the one from the newly discovered gay community was also experienced by Thierry:

Let's say that when you start being involved in the gay community, you...you become quickly really...you become a complete cliché, so you start getting rid of your old clothes and you buy new ones. More and more I started looking like a clone of what I could see in clubs. It's only when I met my partner that I came back to what I was, I left all of that.

Both Michael and Thierry changed their physical appearance to go back to their former look. When asked why he chose to return to "what he was," he explained: 
It [urban gay physical representation]was not for me. I was just doing that to get integrated in some sort of a system. It was not for me to start with, it was not for him either [his partner], and then...it was not natural for me this type of behavior, so I had to readjust myself, you know, becoming who I was.

Throughout the 20th century, in Western Europe in general and in France in particular, there has been a strong binary relationship between masculinity and effeminacy. As noted by Eribon (1999), gay men perceiving themselves as masculine have always expressed disgust, when not hate, toward more feminine gay men. His research shows that they have made a point to dissociate themselves from "folles" ("queens") and the image they portray of homosexuality. In this binary discourse, the "good side" of homosexuality brings together gay but masculine men, who seek to be involved in exclusive long term relationships (therefore "normal"). The "dark side" of homosexuality encourages effeminate identity and performance, and accompanying practices of multiple and brief sexual encounters (therefore "deviant"). This particular study, too, shows that French informants have integrated and reproduced this discourse, but, interestingly, they have "spatialized" it by tending to claim that effeminacy is related to life in the city.

Both American and French informants are likely to perceive the city as a paradoxical space. While growing up and before experiencing it, they perceive the city as a gay "mecca" because of its assumed openness and ease of the collectively visible gay lifestyle. On the other hand, once experienced — particularly through socialization within the gay urban scene- their representations tend to evolve toward more nuanced and conflicted feelings. Immersion in the gay urban scene can be disturbing for young men not knowing the codes and the norms governing this milieu (Valentine and Skelton, 2003). Whether they move to the city or simply visit, young men who grew up in hetero-normative rural places have already developed a value 
system contrasting, potentially, with that existing in the gay urban scene. However, differences

can be seen in the reasons why American and French informants tend to reject the urban scene and its associated gay community: American informants criticize its assumed superficiality, while French informants reject its perceived "effeminizing" power.

\section{Conclusion}

This study shows that the symbolic rural/urban binary suggested by existing literature, in which the city is defined as a "homosexual paradise" and the country is contrasted as a "homosexual vacuum," also reflects the representations by the rural gay men interviewed. While all of these men fantasized the city in their youth, no clear effect of age is apparent on the timing of their return to the country. For both American and French informants, the city holds a central role in their life itineraries as a "must experience" space in order to come to term with their homosexual desires and to develop their homosexual identity. As such, the fulfillment of gay identity seems to impel migration for these rural gay men. Further research is needed to understand the importance of migration for other rural LGBTQ population, and for rural gay men in other countries and regions.

This study does not confirm the existence of unidirectional movements from the country to the city (Binnie, 2004; Brown, 2000; Cant, 1997; Chauncey, 1994; Rubin, 1993; Weston, 1995). Instead we found evidence for Gorman-Murray's argument (2007). The city does not appear as an end point in rural gay men's life itineraries in which they have acquired a definitive and fixed homosexual identity. Back-and-forth movements between and within these two spaces more accurately define informants' life itineraries. The city does not only stand as a liberating space; it is also experienced by young gay men coming from the country as a coercive and 
disciplinary space which can exercise pressure to follow a hegemonic gay identity in which they do not necessarily recognize themselves. While no significant differences were outlined between American and French participants' life itineraries in that both demonstrated rural departure and return, the reasons for rural return and rejection of the urban gay scene appear different. French participants were critical of the effeminacy of the urban gay scene, whereas American participants were critical of its superficiality. For both research populations, this rejection of the city was entwined with internalized rural constructions of masculinity albeit expressed differently.

As discussed earlier, throughout the 20th century and currently, French gay men have repeatedly been represented as effeminate (Eribon, 1999; Le Talec, 2010). This constant representation of gay men reinforces their portrayal of gay men as "the Other," one who is not part of mainstream society (Iglesias-Urquizar, 2009). As a consequence, for French research participants, gaining their collective gay identity brought with it a challenge to their existing individual and collective rural masculine identity and created new internal conflicts around their conceptualization of the "self." Moreover, being an effeminate gay man, in addition to clearly being a stigmatized identity, challenged the French social order by bringing sexual differences to the forefront.

In the United States, the challenge to existing masculine identity is not the contrast with femininity, but rather the visibility of the gay self as on display. American informants' comments seem to echo Bordo's argument about the current cultural definition of masculinity in the United States which rejects presentation of the masculine body as an object created for the gaze of others (Bordo, 1999). While women have traditionally and culturally been the object of the gaze, 
it is the superficial limitations of this identity performance which are explicitly critiqued by American participants, rather than its culturally feminine position.

To find the balance in their masculine and gay identities, both French and American informants engaged in movement from city to country and, often, back again. Growing up in the country, they faced and internalized a strong heterosexual matrix, as defined by Butler (1990), sustaining a discourse — in turn translated into concrete practices — which conflates being masculine with being a man and with being heterosexual. In this space, traditional gender roles and codes appear difficult to transgress. Therefore, developing a gay identity becomes more difficult as it implies stepping outside this heterosexual matrix. Going to the city, perceived as a more transgressive space, becomes the only possible option for these rural gay men to initially experience their same-sex desires and attractions. However, the pressure exercised by the gay scene follow a hegemonic gay identity challenges these rural gay men's attraction to urban space. Thus the experience of the city becomes both liberating and disciplinary; liberating because it allows the exploration of one's same-sex desires and attractions, disciplinary because it is perceived as forcing rural gay men to adopt an identity in which they do not recognize themselves. For these men, coming back to the rural space is therefore equally important for the expression of gay masculine identity.

\section{References}

Ageron, C-R., and Dora, P., 1997. Les Lieux de Mémoire: Tome 3. Gallimard, Paris.

Aldrich, R., 2004. Homosexuality and the City: An Historical Overview. Urban Studies 41, pp. 1719-1737.

Armbrecht, T., 2005. Can One Be "Gay" and French?. The Gay and Lesbian Review, pp. 20-22. 
Andrews, H., 2009. Tits Out for the Boys and No Back Chat: Gendered Space on Holiday. Space and Culture 12, pp. 166-183.

Atkinson, R., 2002. The Life Story Interview. In: Gubrium, J. and Holstein, J., Editors, 2002. Handbook of Qualitative Research. Sage Publication, Thousand Oaks.

Bell, D., 2000. Farm Boys and Wild Men: Rurality, Masculinity, and Homosexuality. Rural Sociology 65, pp.547-561.

Bell, D., 2006. Cowboy Love. In: Campbell, H., Bell, M. and Finney, M., Editors, 2006. Country Boys: Masculinity and Rural Life, Pennsylvania State Press, University Park.

Bell, D. and Valentine, G., 1995. Queer Country: Rural Gay and Lesbian Lives. Journal of Rural Studies 15, pp. 113-122.

Binnie, J., 2004. The Globalization of Sexuality., Sage Publications, London.

Blidon, M., 2008. La casuistique du baiser. L'espace public, un espace hétéronormatif. Echogéo, 5, pp. 2-12.

Blidon, M., 2010. Quartier gay et idéal républicain à la française, un débat mal posé. Bulletin d'histoire politique18, pp. 33-42.

Bonfitto, V., 1997. The Formation of Gay and Lesbian Identity and Community in the Connecticut River Valley of Western Massachusetts, 1900-1970. Journal of Homosexuality 33, pp. 69-96.

Bordo, S., 1999. The Male Body: A New Look at Men in Public and in Private., Farrar, Straus and Giroux, New York.

Bourdieu, P., and Wacquant, L., 1992. An Invitation to Reflexive Sociology., University of Chicago Press, Chicago.

Brown, M., 2000. Closet Space: Geographies of Metaphor from the Body to the Globe., Routledge, London.

Bunce, M., 1994. The Countryside Ideal: Anglo-American Images of Landscape. Routledge, New York.

Butler, J., 1990. Gender Trouble. Feminism and the Subversion of Identity., New York, Routledge.

Calhoun, C., 1994. Social Theory and the Politics of Identity., Blackwell Publishers Malden.

Campbell, H., Bell, M., and Finney, M., 2006. Country Boys: Masculinity and Rural Life., Pennsylvania State Press, University Park. 
Cant, B., 1997. Invented Identities? Lesbian and Gay Talks about Migration., Cassel, London.

Cervulle, M., and Rees-Roberts, N., 2010. Homo Exoticus. Race, Classe et Critique Queer., Armand Colin, Paris.

Charmaz, K., 2006. Constructing Grounded Theory: A Practical Guide Through Qualitative Analysis. London: Sage Publications.

Chauncey, G. 1994. Gay New York: Gender, Urban Culture and the Making of the Gay Male World 1890-1940., Flamingo, London.

Cloke, P., 2007. Rurality and rural otherness. In: Cloke, P., Marsden, T. and Mooney, P., Editors, 2007. Handbook of Rural Studies, Sage Publication, London.

Cloke, P. and Little, J., 1997. Countryside Cultures: Otherness, Marginalization, and Rurality., Routledge, London.

Cody, P., and Welch, J., 1997. Rural Gay Men in Northern New England: Life Experiences and Coping Styles. Journal of Homosexuality 33, pp.51-67.

Connell, R.W. 2005. Masculinities., Allen and Unwin, St. Leonards.

Corbin, J. and Strauss, A. 2007. Basics of Qualitative Research: Techniques and Procedures for Developing Grounded Theory., Sage Publications, Newbury Park.

D'Augelli A. and Hart, M., 1987. Gay Women, Men, and Families in Rural Settings: Toward the Development of Helping Communities. American Journal of Community Psychology 15, pp. 7993.

Eribon, D., 1999. Réflexion sur la question gay. Fayard, Paris.

Fassin, E., 2006. The Rise and Fall of Sexual Politics in the Public Sphere: A Transatlantic Contrast. Public Culture 18, pp. 79-92.

Fone, B., 1983. This Other Eden: Arcadia and the Homosexual Imagination. Journal of Homosexuality 8, pp. 13-34.

Forsyth, A., 1997. Out in the Valley. International Journal of Urban and Regional Research 21, pp. 38-62.

Forsyth, A., 2001. Sexuality and Space: Nonconformist Populations and Planning Practice. Journal of Planning Literature 15, pp. 339-359.

Glaser, B. and Strauss, A., 2006. The Discovery of Grounded Theory: Strategies for Qualitative Research., Aldine Transaction, New Brunswick. 
Gorman-Murray, A., 2007. Rethinking Queer Migration Through the Body. Social and Cultural Geography 8, pp. 105-121.

Gorman-Murray, A., Waitt, G., and Gibson, C., 2008. A Queer Country? A case study of the politics of gay/lesbian belonging in an Australian country town. Australian Geographer, 39, pp. 171-191.

Gray, M. 2009. Out in the Country: Youth, Media, and Queer Visibility in Rural America., NYU Press, New York.

Haraway, D., 1988. Situated Knowledge: The Science Question in Feminism and the Privilege of Partial Perspectives. Feminist Research 14, pp. 575-599.

Iglesias-Urquizar, J., 2009. Man or Mouse?: Representations of Masculinity in American Television and Film, 1998-2008. M.A. Thesis, South Dakota State University, Department of English.

Inness, S., 2004. Lost in Space: Queer Geography and the Politics of Location. In: Carlin D., and J. DiGrazia, Editors. Queer Cultures, Pearson, Upper Saddle River.

Johnstone, C., 2008. (Post-)Queer Citizenship in Contemporary Republican France.

Contemporary French and Francophone Studies 12, pp. 89-97.

Johnstone, L. and Longhurst, R., 2010. Space, Place, and Sex: Geographies of Sexualities.Rowman and Littlefield Publishers, Plymouth.

Howard, J., 1999. Men Like That: A Southern Queer History. University of Chicago Press, Chicago.

Kirkey, K., and Forsyth, A., 2001. Men in the valley: gay male life on the suburban-rural fringe. Journal of Rural Studies 17, pp. 421-441.

Knopp, L., 1998. Sexuality and Urban Space: Gay Male Identity Politics in the United States, the United Kingdom and Australia. In Fincher R., and J. Jacobs, Editors, 1998. Cities of Difference. Guildford Publishers, London.

Knopp, L., 2006. Movement and Encounter. In: Valentine, G., and Aitken, S., Editors, 2006. Approaches to Human Geography. Sage Publications, London.

Knopp, L., and Brown, M., 2003. Queer Diffusions. Environment \& Planning D: Society \& Space 21, pp. 409-424.

Kong, T., Mahoney, D. and Plummer, K., 2002. Queering the Interview. In: Gubrium, J., and Holstein, J., Editors, 2002. Handbook of Qualitative Research, Sage Publications, Thousand Oaks. 
Kramer, J-L., 1995. Bachelor Farmers and Spinsters: Gay and Lesbian Identities and Communities in Rural North Dakota. In: Bell, D. and Valentine, G., Editors, 1995. Mapping Desire: Geographies of Sexualities. Routledge, London.

La Palestina, A., 2006. The Implications of an Ethnographer"s Sexuality. Qualitative Inquiry, 12: 724-735.

Le Talec, JY., 2010. Folles de France: Repenser l“chomosexualité masculine., Edition La découverte, Paris.

Lipsitz, G., 2006. How White People Profit from Identity Politics. Temple University, Philadelphia.

Little, J., 2002. Gender and Rural Geography., Pearson, London.

Little, J., 2003. 'Riding the rural love train': Heterosexuality and the rural community. Sociologia Ruralis 43, pp. 401-417.

Little, J., and Austin, P., 1996. Women and the rural idyll. Journal of Rural Studies 12, pp. 101111.

Little, J., and Panelli, R., 2007. „Outbacke Romance? A Reading of Nature and Heterosexuality in Rural Australia. Sociologia Ruralis 47, pp. 173-186.

Loffreda, B., 2000. Losing Matt Shepard: Life and Politics in the Aftermath of Anti-Gay Murder., Columbia University Press, New York.

Martel, F., 1999. The Pink and the Blacks: Homosexuals in France since 1968., Stanford Press University, Palo Alto.

Mendras, H., 1992. La fin des paysans. Actes Sud, Paris.

Mort, F., 1995. Archaeologies of city life: commercial culture, masculinity and spatial relations in 1980s London. Environment and Planning D: Society and Space 13, pp. 573-590.

Moses, A.E. and Hawkins, R., 1980. The Special Problems of Rural gay Clients. Human Services in the Rural Environment 5, pp. 22-27.

Panelli, R., Hubbard, P., Coombes, B. and Suchet-Pearson, S., 2009. De-centring White ruralities: Ethnic diversity, racialisation and Indigenous countrysides. Journal of Rural Studies 25 , pp 355-364.

Robinson, V., 2008. A Different Kind of Hard: Everyday Masculinities., Identity and Rock Climbing. Berg Publishers, Oxford. 
Rose, G., 1993. Feminism and Geography: the limits of geographical knowledge., Polity Press, Cambridge.

Rubin, G., 1993. Thinking Sex: Notes for a Radical Theory of the Politics of Sexuality. In: Abelove, H., Barale, M. and Halperin, D., Editors, 1993. The Lesbian and Gay Studies Reader, Routledge, London.

Sasson-Levy, O., 2002. Constructing Masculinities at the Margins: Masculinities and Citizenship in the Israeli Army. Sociological Quarterly 43, pp. 357-383.

Saugeres, L., 2002. The Cultural Representation of the Farming Landscape: Masculinity, Power and Nature. Journal of Rural Studies 18, pp. 373-384.

Shuttleton, D., 2000. The Queer Politics of gay Pastoral. In: P. Philips, Watt, D. and Shuttleton,D., Editors, 2000. De-Centring Sexualities: Politics and Representations Beyond the Metropolis, London, Routledge.

Smith, D. and Holt, L., 2005. Lesbian migrants in the gentrified valley and "other" geographies of rural gentrification. Journal of Rural Studies 21, pp. 313-321.

Tin, L-G., 2008. L“Invention de la Culture Hétérosexuelle., Éditions Autrement, Paris.

Valentine, G., 1997. Making Space: Lesbian Separatist Communities in the United States. In: P. Cloke and Little, J., Editors, 1997. Contested Countryside Cultures: Otherness, Marginalization, and Rurality, Routledge, London.

Valentine, G., and Skelton, T., 2003. Finding Oneself, Losing Oneself: The Lesbian and Gay "Scene" as a Paradoxical Space. International Journal of Urban and Regional Research 27, pp. 849-866.

Vepsalainen, M., and Pitkanen, K., 2010. Second Home Countryside. Representations of the Rural in Finnish Popular Discourses. Journal of Rural Studies 26, pp. 194-204.

Warren, C., 2002. Qualitative Interviewing. In: J. Gubrium and J. Holstein, Editors. Handbook of Qualitative Research. Sage Publication, Thousand Oaks.

Weston, K., 1995. Get to a Big City: Sexual Imaginary and the Great Gay Migration. Gay and Lesbian Quarterly 3, pp. 253-277.

Woodward, K., 2002. Understanding Identity., Arnold Publishers, London. 